\title{
Is Caribbean tourism in overdrive? Investigating the antecedents and effects of overtourism in sovereign and nonsovereign small island tourism economies (SITEs)
}

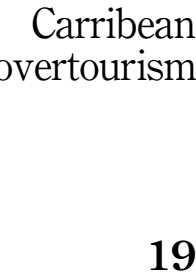

Received 2 July 2020 Revised 14 October 2020 6 December 2020 Accepted 13 January 2021

\author{
Central Bank of Aruba, Oranjestad, Aruba, and \\ Robin B. DiPietro \\ School of Hotel, Restaurant and Tourism Management, University of South Carolina, \\ Columbia, South Carolina, USA
}

Ryan Peterson

\begin{abstract}
Purpose - Drawing on theories of development economics and sustainable tourism, this research explores the differences between sovereign and nonsovereign small island tourism economies (SITEs) and identifies the antecedents and effects of overtourism in the Caribbean.

Design/methodology/approach - The research design is based on a comparative case study of selected Caribbean SITEs. Case study research involves a detailed empirical inquiry that investigates a contemporary phenomenon within its real-life context. The main purpose of a case study is to provide a contextual analysis of the conditions and processes involved in the phenomenon under study. A comparative case study is an appropriate research methodology to explore new multi-faceted concepts with limited empirical evidence.

Findings - The results confirm previous studies that nonsovereign SITEs have a distinctive overdrive toward tourism specialization. Moreover, the findings indicate that overtourism is driven by both global and domestic policy factors and generates significant economic volatility, social inequality and ecological stress. The paper discusses the tourism policy implications of the evolving economic disconnectedness, environmental decay and social tensions in SITEs in the Caribbean.

Originality/value - Policy recommendations are presented for transitioning toward a more inclusive development and strengthening the resilience of small island tourism development in the Caribbean.

Keywords Small island tourism economy, Overtourism, Nonsovereign island states, Resilience, Caribbean Paper type Research paper

\section{Introduction}

It is a truism that international tourism is part and parcel of the Caribbean. Over the past century, tourism arrivals have grown tenfold, from less than five million visitors during the early 1970s to well over 36 million tourists in 2017 (Statista, 2020). Since the turn of the century, Caribbean tourism growth tripled (United Nations World Tourism Organization [UNWTO], 2019) and is expected to continue to grow over the next decade (World Travel and Tourism Council[WTTC], 2019). Recent tourism industry reports indicate that the Caribbean is gearing up for another tourism growth burst, attracting new hotel investors and well over 31,000 new accommodations in the construction pipeline (Britell, 2020). The Caribbean is

(C) Ryan Peterson and Robin B. DiPietro. Published in International Hospitality Review. Published by Emerald Publishing Limited. This article is published under the Creative Commons Attribution (CC BY 4.0) licence. Anyone may reproduce, distribute, translate and create derivative works of this article (for both commercial and non-commercial purposes), subject to full attribution to the original publication and authors. The full terms of this licence may be seen at http://creativecommons.org/licences/by/4.0/ legalcode
\end{abstract}

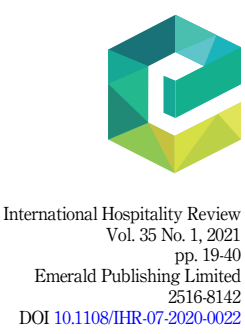


IHR

35,1

indeed one of the most tourism-intense regions of the world with international tourism contributing, on average, to $20 \%$ of exports, $15 \%$ of GDP (gross domestic product) and $14 \%$ of labor (WTTC, 2019). Likewise, accounting for at least $13 \%$ of capital investments (WTTC, 2019), international tourism is one of the most resource-intense industries, including financial, human and natural resources (McElroy, 2006). In the wake of the global COVID-19 pandemic, the unprecedented plunge in Caribbean travel and tourism is a clear and present sign of both the value and the vulnerability of tourism across the Caribbean (International Monetary Fund - IMF, 2020).

Despite this significant and continued tourism growth, there are increasing signs that economic growth has largely stagnated across the Caribbean, especially in the smaller and more tourism-dependent island economies (Acevedo et al., 2017; Peterson, 2019; Leigh et al., 2017). Initial evidence suggests that the surge in international tourism has not contributed significantly to the lackluster economic growth since the early 2000s (Chamon et al., 2017). Whereas tourism arrivals and accommodations have expanded and continue to grow across the Caribbean, tourism expenditures have not increased commensurately (Acevedo et al., 2017). Therefore, the purpose of this exploratory study is to (1) investigate the status and qualities of overtourism in sovereign and nonsovereign Caribbean small island tourism economies (SITEs) and (2) examine the antecedents and effects of overtourism in mature SITEs in order to determine implications for industry and academics to help create a more sustainable model for small island tourism development.

This reality of overtourism is consistent with previous studies reporting stagnant growth and diminishing productivity in Caribbean tourism economies (Acevedo et al., 2017; Peterson, 2017). Moreover, the performance of SITEs has lagged other (non-) Caribbean small island economies for at least a decade (Acevedo et al., 2017). Thus, the confluence of enduring tourism growth with diminishing economic development in SITEs raises questions about the role and contribution of tourism for sustainable and inclusive development in the Caribbean (United Nations Sustainable Development Goals (UNSDG), 2018), especially considering the complex of economic and environmental shocks in addition to the longstanding social vulnerabilities and institutional weaknesses (International Monetary Fund [IMF], 2019; Peterson, 2019).

When a country has a focus on tourism as an economic advantage and a significant export industry, it is traditionally associated with economic production and growth (Brida et al., 2016; Cannonier and Galloway, 2019; Croes, 2006; Croes et al., 2021; Marsiglio, 2018). There are also potential adverse externalities related to this tourism specialization (Daye et al., 2008; Dodds and Butler, 2019a; Duval, 2004; Gossling, 2002; Hall and Williams, 2008; McElroy, 2003; Peterson, 2009; Wilkinson, 1989). The tourism-led growth hypothesis proposes international tourism drives economic growth (Brida et al., 2016). However, several studies indicate that this relationship is intermediated and moderated by several other contingency factors and tourism destination-specific conditions, including the capacity to adapt to and absorb large-scale, high-pace tourism construction and growth (Bishop, 2010; Cole, 2007; McElroy, 2006). The relationship between tourism specialization and economic growth is moderated by absorptive capacities (Acemoglu and Robinson, 2012; Baldacchino, 2006; Brautigam and Woolcock, 2001; Peterson, 2017), which describe the optimum level of tourism specialization that can be assimilated and absorbed by an economy before reaching an inflection point after which tourism specialization experiences diminishing returns and negative externalities (Dodds and Butler, 2019a; Marsiglio, 2018).

When reviewing the history of tourism in the Caribbean, it is increasingly apparent that growth rather than development remains the overriding focus, i.e. the quality of life for residents and, in turn, the quality of experience for visitors have not always met the various principles of sustainable tourism (Daye et al., 2008; Duval, 2004; Joppe, 2019; Scheyvens and Biddulph, 2017). In fact, economic considerations and benefits of tourism specialization tend 
to induce tourism myopia - a short-term growth orientation on tourism arrivals, receipts and (tax) revenues - and trigger a gradual tourism overshoot of socioecological ceilings with significant costs in the medium to long term (Dodds and Butler, 2019b; Ewing-Chow, 2019; Joppe, 2019; Marsiglio, 2017; Raworth, 2017).

Crandall (1994) concludes that while tourism is accepted as a significant boon to local economies, there is little realization on the part of government, tourism authorities and investors that tourism leads to economic spillovers, social changes and ecological challenges, especially when unplanned or uncontrolled. Although, certainly, this is not a new experience, this accelerating tourism spillover effect has recently been coined "overtourism" (Dodds and Butler, 2019b; Goodwin, 2017). Thus, coping with the short-term economic success of tourism growth is inextricably linked to managing and mitigating the risks of overtourism in contemporary tourism destinations (WTTC, 2019).

Whereas previous research on international tourism in the Caribbean focuses almost exclusively on the sovereign (independent) small island tourism states, nonsovereign (dependent) island tourism economies are generally less scrutinized and often excluded, largely due to their nonsovereign political status. Ironically, these subnational island jurisdictions are oftentimes relatively more tourism intense and prone to overtourism (Baldacchino, 2006; McElroy, 2006; Peterson, 2019; WTTC, 2019). Therefore, the heterogenous nature of Caribbean tourism economies, consisting of both sovereign island states and subnational jurisdictions, calls for the explicit acknowledgment and incorporation of subnational island jurisdictions in tourism studies, especially considering the political economic context of small island tourism development (Armstrong and Read, 2000; Daye et al., 2008; McElroy, 2006). In fact, over the past decade, several studies have called for research on the political economy of small island tourism development in the (British, Dutch and French) dependencies in the Caribbean (Baldacchino, 2006; Bishop, 2010; Daye et al., 2008; McElroy, 2006).

Consequently, this paper addresses the current state of overtourism in sovereign and nonsovereign SITEs in the Caribbean. The aim of this exploratory study is to (1) investigate the status and qualities of overtourism in sovereign and nonsovereign Caribbean SITEs and (2) examine the antecedents and effects of overtourism in mature SITEs. In Section 2, the theoretical background of this study is discussed by reviewing the conceptual origins and mechanisms of overtourism. The research methodology is described in Section 3, followed by a presentation of the main findings, while conclusions and recommendations are presented in the final part of the paper.

\section{Theoretical background}

In general, overtourism describes the adverse impacts of uncontrolled tourism growth - an overshoot of tourism - that influences the quality of life and the well-being of citizens and the degradation of natural habitats and ecologies, which result in diminishing visitor experiences and expenditures, and consequently stagnating economic returns (United Nations World Tourism Organization - UNWTO, 2018). Overtourism portrays relentless, frequently unregulated, tourism growth that has moved beyond the level of acceptable change and absorptive capacity in a destination due to significant levels of tourism intensity (total visitors to population), tourism density (visitors per $\mathrm{km}^{2}$ ) and tourism dependency (tourism exports to GDP) (McElroy, 2006; World Travel and Tourism Council - WTTC, 2019). The compounding and composite effects result in significant pressures on infrastructure (i.e. congestion, transportation and energy), resource consumption and pollution (i.e. leakage and waste), spatial and cultural alienation (i.e. real estate and social identity) and visitors' experiences and residents' quality of life (Center for Responsible Travel-CERT, 2018; World Travel and Tourism Council - WTTC, 2019).

\section{Carribean overtourism}


IHR

35,1

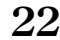

The genesis of overtourism dates back to at least the 1970s and 1980s when initial concerns were raised about the potential adverse social and environmental impacts of uncontrolled tourism growth and consequently the long-run economic repercussions thereof (Budowski, 1976; Butler, 1980; Cohen, 1978; Doxey, 1978; Dunkel, 1984; Farrell and Runyan, 1991; Getz, 1983; Holder, 1988; Mathieson and Wall, 1982; Richter, 1994; Wilkinson, 1989). By the early 2000s, several empirical studies reported on the negative externalities of tourism in SITEs (Bishop, 2010; Duval, 2004; McElroy, 2003, 2006; Sheller, 2003). Over the past decade, further evidence has been forthcoming on the role and rise of overtourism, albeit mainly focused on metropolitan areas and cities (Capocchi et al., 2019; CERT, 2018; Dodds and Butler, 2019b).

As a concept, overtourism is rooted in development economics and discussions on overdevelopment, overdependency and overconsumption (Kohr, 1977; Meier and Stiglitz, 2001). From a postdevelopment theoretical perspective (Cowen and Shenton, 1996), overtourism refers to the social inequality and the environmental destruction due to excessive tourism consumption and tourism-related infrastructure expansion (Raworth, 2017). Overtourism is conceptually embedded in the study of how economies grow and societies change over the course of history (Meier and Stiglitz, 2001) and is frequently viewed in negative terms as the mutually constitutive reverse of inclusive development (Gupta and Vegeling, 2016; UNSDG, 2018; World Bank, 2018).

In development economics, it is not only the rate of real GDP per capita growth that matters but also more importantly the pattern of labor force participation and income distribution in growth (Meier, 2001). Inclusive development focuses on productive employment as a means of increasing income as well as raising standards of living and economic well-being (Gupta and Vegeling, 2016; Ianchovichina and Lundstrom; 2009; Rainir and Ramos, 2013; Rauniyar and Kanbur, 2010). Gupta and Vegeling (2016) emphasize the social and ecological aspects of inclusive development. Whereas social elements address citizen well-being and participation in labor and consumption markets, ecological elements concentrate on the conservation of local ecosystems, the management of ecosystem services and the regulation of environmental resources. Inclusive development stems from the realization that relentless economic growth often gives rise to negative externalities, extractive resource depletions and exploitative labor practices (Raworth, 2017), which are clear and present features of overtourism and readily acknowledged in SITEs (Daye et al., 2008; Duval, 2004; Island Resource Foundation, 1996; McElroy, 2006; Pattullo, 1996; Sheller, 2003).

According to Scheyvens and Biddulph (2017), one of the most enduring critiques of tourism is its noninclusive development. They contend that tourism oftentimes provides opportunities for the privileged, creating profits for international (nonlocal) resorts and building exclusive enclaves for the rich, thereby excluding the indigenous community, marginalizing local cultures and lifestyles and depleting scarce natural resources (Scheyvens and Biddulph, 2017). In reflecting on the tourism overdependency in the Caribbean, Daye et al. (2008) indicate that there is significant economic volatility and leakage due to the outflow of capital. Duval (2004) concludes that if left uncontrolled, Caribbean tourism often leads to environmentally extractive and socially exclusive developments, which in the long run undermine future economic development. It is the unbalanced and unequal distribution of benefits and costs amongst stakeholders that nourishes overtourism.

Overtourism extends previous theoretical frameworks and models of tourism lifecycles and complex adaptive tourism systems. The origins can be traced back to notions of the tourism destination life cycle (Butler, 1980) and tourism carrying capacity (Mathieson and Wall, 1982), which have been widely discussed in the Caribbean. The concept of overtourism underscores the nonlinear, interdependent and dynamic nature of tourism systems, which encompass several interacting social, political, economic, ecological and digital subsystems, 
especially within the small(er) scale of island economies (Peterson et al., 2017). These complex adaptive tourism systems are "nested" or embedded within social ecologies and often evolve in distinct ways with extensive cascades of uncertain and oftentimes path dependent and long-term effects (Dodds and Butler, 2019b; Farrell and Twining-Ward, 2004).

In reflecting on the growth of Caribbean tourism, McElroy (2006) contends that part of the problem in the Caribbean is that much of the tourism growth during the late 1990s was too fast and fragmented. According to Farrell and Runyan (1991), this rapid and unbalanced growth of tourism produces an inherent propensity for environmental overrun and sociocultural disruption, which in due course would affect industry viability and economic sustainability. As the intensity and concentration of tourism growth increases, the capacity of delicate socioecological island systems to absorb these changes can be drastically exceeded and may produce undesirable resource degradation (Farrell and Runyan, 1991).

Due to their relatively limited size and scale, small states and islands tend to be more susceptible to external pressures and internal disturbances. Unlike the tangible economic benefits (e.g. employment exports, and foreign exchange earnings) that accrue in the short term, the long-term costs (e.g. beach erosion, coastal pollution, congestion and social inequality and poverty) often remain concealed until critical thresholds are crossed (McElroy, 2003). Whereas exogenous shocks occur in a sudden and disruptive manner, the externalities of overtourism cascade gradually over time until spilling over into the public domain.

The case in point is especially poignant in Caribbean SITEs that rely on their natural and social ecologies for safeguarding economic development and well-being. Whereas sustainable tourism requires the conservation of ecological integrity and environmental resources, its production is, paradoxically, largely dependent upon the consumption of nature-based tourism experiences (Williams and Ponsford, 2008). Likewise, whereas much of Caribbean tourism is staged by its cultural authenticity and natural hospitality, its production is labor-intensive with exhaustive demands on emotional labor (Shani et al., 2014; Sönmez et al., 2017). This ambiguity has epitomized much of the progress, pitfalls and perils of Caribbean tourism over the past century (Duval, 2004).

In discussing the ambiguous role of tourism as a small state development strategy in the Eastern Caribbean, Bishop (2010) concludes that despite offering real economic opportunities, tourism growth is far from being a silver bullet due to its impact on fragile marine environments, social dislocations and economic vulnerability. The amalgamation of these spillovers may bring about negative sentiments toward visitors as well as tourism labor immigrants (McElroy, 2003), thereby giving rise to social tensions and tourism backlash as experienced in several popular international tourism destinations over the past decade (Dodds and Butler, 2019b). Based on theoretical assumptions of development economics and previous tourism studies, the following proposition is put forward:

Proposition 1. Higher levels of overtourism in Caribbean SITEs are positively associated with lower labor force participation, more ecological stress and higher economic volatility.

The general effects of overtourism are frequently transmitted through direct as well as indirect channels (Scheyvens and Biddulph, 2017). Direct channels of overtourism transmission describe diminishing real GDP growth, economic volatility, stagnant tourism contribution to GDP, declining average visitor expenditures, increasing import leakages, growing resource consumption and tourism price inflation (Acevedo et al., 2017). Overtourism also transmits through indirect channels, which affect local communities and natural habitats (Scheyvens and Biddulph, 2017). Indirect channels of overtourism transmission include declining labor force participation rates, uneven income distribution, foreign-ownership concentration of tourism industry, spatial concentration of tourism industry, real-estate price inflation, environmental degradation, loss of natural habitats and diminishing contribution of

\section{Carribean overtourism}


IHR

35,1

tourism ecological services (Capocchi et al., 2019; Daye et al., 2008; Dodds and Butler, 2019b; Duval, 2004; Joppe, 2019; Koens et al., 2018; McElroy, 2006). However, unlike direct transmission channels of overtourism, indirect effects often transpire and materialize in the medium to long term. Therefore, the following proposition is presented:

Proposition 2. The impact of overtourism in Caribbean SITEs is transmitted through both direct channels as well as indirect channels.

Previous studies indicate that overtourism stems from the complex dynamics of international tourism demand and local tourism supply (Acevedo et al., 2017; Capocchi et al., 2019; Daye et al., 2008; Cole, 2007; Dodds and Butler, 2019b; Farrell and Twining-Ward, 2004; Joppe, 2019; Koens et al., 2018; McElroy, 2006. In reviewing the progressive development and potential challenges of tourism growth across SITEs, McElroy (2003, 2006) discusses different interrelated causes of a tourism overrun, defined as high-density tourism with damaging levels of visitation due to tourism's sociocultural pressures and environmental footprint. The critical factors that spur overtourism in the Caribbean include the substantial inflow of foreign private tourism investments; the significant stock and rapid expansion of large-scale accommodation facilities; the growth in air traffic and cruise calls; the increase in labor immigration and the subsequent rise in unplanned coastal urbanization and real-estate infrastructures (McElroy, 2003, 2006). Previous studies indeed confirm that this system of an interlocked tourism supply chain, including the interlinked growth in tourism investments and airlift and the subsequent expansion of accommodations and required labor, contributes to surging levels of tourism intensity and density in the Caribbean (Acevedo et al., 2017), which gradually engender a state of overtourism in SITEs (Cole, 2007; McElroy, 2006).

Furthermore, several structural features are conducive to overtourism, involving geographic proximity to affluent origin markets, fixed foreign exchange rate, progrowth economic policies and a political status, that foster political stability and access to international financing of infrastructure developments (McElroy, 2003, 2006). Bertram (2004) concludes that island economies whose close political linkages to former colonial powers survived the transition to the postcolonial era were the ones exhibiting relatively higher levels of economic growth up to the turn of the century. Baldacchino (2006) indicates that this relative success is directly linked to their degree of diligently managed and negotiated trade (including tourism) and the political use of simultaneous economic autonomy and close jurisdictional ties. Consequently, it is likely that these political linkages play a significant role in explaining the manifestation of overtourism in sovereign Caribbean SITEs. Based on previous studies (McElroy, 2003, 2006) and Bertram (2004) this study hypothesizes that sovereign Caribbean SITEs are relatively more prone to overtourism:

Proposition 3. In comparison to nonsovereign Caribbean SITEs, sovereign Caribbean SITEs experience significantly higher levels of overtourism.

Cole (2007) indicates that an overshoot in Caribbean tourism arises from several interdependent factors, including growing tourism demand; surpassing physical limits of beachfront or coastal areas for resort construction; increasing labor migration due to limited local workforce; growing visitors' sense of overcrowding and an escalation in residents feeling overwhelmed or displaced by visitors and/or immigrant workers. The latter describes intensifying sentiments of visitor annoyance and apathy by local communities (Doxey, 1978). The unfolding of these events triggers a spiral of demise where surging small island coastal tourism causes increasing crowding, congestion and contamination. Frequently, this leads to irreversible ecological destruction, social decay and aesthetic repulsion and a further uncontrolled spiraling effect (Dehoorne et al., 2010).

In addressing the dominance of political linkages in nonsovereign island economies (Bertram, 2004) and the political economy of tourism development in small islands, several 
studies discuss the influence of (inter)institutional actors and networks of power and control that shape tourism policies and influence tourism developments adversely (Baldacchino, 2006; Crandall, 1994; Duval, 2004; Bishop, 2010; Joppe, 2019; Richter, 1994). The political economy of Caribbean island tourism is oftentimes riddled by exclusion and extraction rather than inclusion and regeneration (Bishop, 2010; Daye et al., 2008; Duval, 2004; McElroy and Albuquerque, 2002). Crandall (1994) and Richter (1994) contend that these tensions stem from a combination of factors, including narrow and concentrated economic beneficiaries of tourism, land disputes, increasing public-sector infrastructure strains and taxes, rising costs of living, excessive migration with limited career opportunities and social dislocations. According to Baldacchino (2006) and Bertram (2004), these features are closely intertwined with the political economy of nonsovereign island economies.

The confluence of these failures intensify the negative externalities due to several structural political economic conditions, including (1) a regulatory deficiency in environmental conservation and enforcement, (2) limited economic diversification and innovation, (3) lopsided (private) benefits and (public) costs of tourism growth, (4) marginal social inclusion and nongovernmental participation in tourism policy and development and (5) a strong and persistent bias toward short-term tourism promotion, expansion and growth (Bishop, 2010; Cole, 2007; Daye et al., 2008; Dodds and Butler, 2019b; Joppe, 2019; McElroy, 2003). Moreover, Williams and Ponsford (2008) argue that politically-linked public institutions and agents tend to circumvent regulations and regulatory enforcement largely due to the economic "lock-in" of the tourism industry. Hall and Williams (2008) describe this tourism "lock-in" as path dependency, which is conducive to institutional failures (e.g. close personal and political ties and resource dependency), network failures (e.g. dissonance and ignorance of new developments) and capability failures (e.g. lack of institutional learning capabilities).

Underscoring the importance of institutional failures, Dodds and Butler (2019b) conclude that a key political economic enabler of overtourism is the mutually reinforcing attitude, or mindset, of both private- and public-sector stakeholders that favor short-term growth above all else, which subsequently nurtures institutional bonding and "blindness" (Hall and Williams, 2008). According to Nikola (2019), more often than not, government and tourism authorities contend that the problem of "too much tourism" does not exist or relate to their specific tourism jurisdictions. Based on previous tourism studies and findings, the following proposition is set forth:

Proposition 4. Higher levels of overtourism are associated with both international tourism demand as well as interdependent tourism supply factors.

In conclusion, whereas growing international tourism demand creates the conditions for overtourism, several interdependent domestic supply factors are regarded as the key determinants that drive overtourism (Acevedo et al., 2017; Bishop, 2010; Cole, 2007; Dodds and Butler, 2019b; Duval, 2004; Joppe, 2019; Hall and Williams, 2008; McElroy, 2006; Richter, 1994; Williams and Ponsford, 2008). Overtourism is likely to ascend when both push and pull forces are mutually reinforcing, i.e. surging demand and expansionary supply. Consequently, the confluence and acceleration of multiple tourism demand and tourism supply forces shape the evolution of overtourism in Caribbean SITEs.

\section{Research methodology}

The aim of this exploratory study is to (1) investigate the status and qualities of overtourism in sovereign and nonsovereign Caribbean SITEs, and (2) examine the antecedents and effects of overtourism in mature SITEs. The two main research questions addressed are as follows: (1) how do sovereign and nonsovereign SITEs in the Caribbean differ? (2) what are the main drivers and impacts of overtourism in selected Caribbean SITES?

\section{Carribean overtourism}


IHR

35,1

\section{6}

Table 1.

Stylized indicators of selected sovereign and nonsovereign Caribbean SITEs

(CTO, 2020; UNWTO, 2019; WB, 2018; WTTC, 2019)

\subsection{Data compilation}

Based on previous studies and available secondary historical data covering the years between 2000 and 2018 (Caribbean Tourism Organization-CTO, 2020; United Nations World Tourism Organization-UNWTO, 2019; World Bank-WB, 2018; World Travel and Tourism Council-WTTC, 2019), sixteen (16) Caribbean SITEs were selected including both sovereign and nonsovereign SITEs (see Table 1). The sovereign SITEs comprise Antigua and Barbuda, The Bahamas, Barbados, Dominica, Grenada, St. Kitts and Nevis, St. Lucia and St. Vincent and the Grenadines. The nonsovereign SITEs consist of Anguilla, Aruba, Bermuda, British Virgin Islands, Cayman Islands, Martinique, St. Maarten and the US Virgin Islands. Several Caribbean island tourism-dependent economies were excluded due to their relatively larger population size and land mass (e.g. Jamaica) or limited/incomplete data (e.g. Turks and Caicos). Previous studies indicate that both population size and land mass influence the shape and style of (over)tourism growth (Briguglio et al., 1996; Cole, 2007; McElroy, 2006). Likewise, this study acknowledges that Caribbean SITEs differ in their style and stage of tourism development, and in fact, a key element of interest in this study is whether sovereign and nonsovereign SITEs differ in any systematic manner.

Building forth on previous studies, the following indicators and measurements were used subject to the availability of sufficient and complete data. The overtourism construct is formed by a composite of three sub-indicators including tourism intensity (total visitors to population), tourism density (visitors per $\mathrm{km}^{2}$ ) and tourism dependency (tourism exports to GDP) (Cole, 2007; Dodds and Butler, 2019b; McElroy, 2006). The tourism arrivals, cruise

\begin{tabular}{|c|c|c|c|c|c|c|}
\hline Country & $\begin{array}{l}\text { Political status } \\
\text { (sovereignty) }\end{array}$ & $\begin{array}{c}\text { Population } \\
\text { density } \\
\text { (Population/ } \\
\mathrm{km}^{2} \text { ) } \\
\end{array}$ & $\begin{array}{l}\text { Tourism } \\
\text { density } \\
\text { (total } \\
\text { visitors/ } \\
\mathrm{km}^{2} \text { ) }\end{array}$ & $\begin{array}{l}\text { Resort } \\
\text { density } \\
\text { (hotel } \\
\text { rooms/ } \\
\mathrm{km}^{2} \text { ) } \\
\end{array}$ & $\begin{array}{c}\text { Tourism } \\
\text { intensity } \\
\text { (total } \\
\text { visitors/ } \\
\text { capita) }\end{array}$ & $\begin{array}{c}\text { Total GDP } \\
\text { contribution } \\
\text { (\% of GDP) }\end{array}$ \\
\hline Anguilla & Nonsovereign & 163 & 2,396 & 10 & 15 & 62 \\
\hline Antigua and & Sovereign & 220 & 2,109 & 9 & 10 & 52 \\
\hline Aruba & Nonsovereign & 622 & 10,539 & 40 & 17 & 87 \\
\hline $\begin{array}{l}\text { The } \\
\text { Bahamas }\end{array}$ & Sovereign & 28 & 292 & 1 & 10 & 48 \\
\hline Barbados & Sovereign & 668 & 3,047 & 13 & 5 & 41 \\
\hline Bermuda & Nonsovereign & 1,343 & 14,453 & 40 & 11 & 17 \\
\hline $\begin{array}{l}\text { British } \\
\text { Virgin } \\
\text { Islands }\end{array}$ & Nonsovereign & 199 & 3,046 & 4 & 15 & 70 \\
\hline $\begin{array}{l}\text { Cayman } \\
\text { Islands }\end{array}$ & Nonsovereign & 246 & 7,951 & 15 & 32 & 30 \\
\hline Dominica & Sovereign & 96 & 609 & 1 & 6 & 33 \\
\hline Grenada & Sovereign & 326 & 1,334 & 5 & 4 & 23 \\
\hline Martinique & Nonsovereign & 333 & 934 & 3 & 3 & 14 \\
\hline $\begin{array}{l}\text { St. Kitts and } \\
\text { Nevis }\end{array}$ & Sovereign & 202 & 4,195 & 6 & 21 & 27 \\
\hline St. Lucia & Sovereign & 339 & 1820 & 8 & 5 & 42 \\
\hline $\begin{array}{l}\text { St. Vincent } \\
\text { and the } \\
\text { Grenadines }\end{array}$ & Sovereign & 284 & 728 & 10 & 3 & 46 \\
\hline St. Maarten & Nonsovereign & 1,247 & 36,088 & 78 & 29 & 78 \\
\hline $\begin{array}{l}\text { USVirgin } \\
\text { Islands }\end{array}$ & Nonsovereign & 301 & 4,262 & 9 & 14 & 59 \\
\hline
\end{tabular}


visitor, population and trade data were drawn from the tourism publications and databases of the CTO, 2020, the UNWTO, 2019, the World Bank (WB, 2018) and the WTTC, 2019 and used to calculated to sub-indices of overtourism tourism intensity, tourism density and tourism dependency. To test for heteroskedasticity under assumption of nonlinearity, the White test was conducted with no significant effects (Chi-Square $=20 ; p>0.05$ ).

The dependent variables comprise the direct and indirect transmission channels of overtourism and are based on previously operationalized measurements by Capocchi $e$ t al. (2019), Daye et al. (2008), Dodds and Butler (2019b), Duval (2004), Gupta and Vegeling (2016), Joppe (2019), Koens et al. (2018) and McElroy (2003, 2006). Data on economic growth, income inequality, labor force participation and environmental pollution data were compiled from several databases from the CTO (2019a, b), the UNWTO (2019) and the WB (2018).

Likewise, the variables describing international tourism demand and domestic tourism supply are based on previous tourism studies (Acevedo et al., 2017; Bishop, 2010; Cole, 2007; Dodds and Butler, 2019b; Duval, 2004; Joppe, 2019; Hall and Williams, 2008; McElroy, 2006; Richter, 1994; Williams and Ponsford, 2008). Based on tourism data from the UNWTO (2018), the WTTC (2019) and the WB (2018), tourism demand and supply were measured by the relative destination market share of Caribbean tourism arrivals, amount of airlift, number of accommodations and the size of tourism labor force (Acevedo et al., 2017; Cole, 2007; McElroy, 2006; Richter, 1994). Furthermore, from an infrastructure perspective, the number and (spatial) concentration of cruise arrivals as well as resorts was measured. The number of rooms per resort was used as proxy measure for resort style (McElroy, 2006). The degree of tourism export specialization was calculated by analyzing tourism receipts, the ratio of tourism exports to GDP and total imports and exports as percentage of GDP (WTTC, 2019; $\mathrm{WB}, 2018)$.

\subsection{Analyzing significant differences in overtourism}

To identify the differentiating features of overtourism across sovereign and nonsovereign SITEs (see Proposition 3) and consistent with previous studies and measures (McElroy, 2003, 2006), the data were standardized across several indicators in order to normalize the data and facilitate comparative and inferential analyses. Available country data are standardized by using a min-max scaling method. The general formula for the min-max scaling $(0,1)$ is the following: $y=(x-\min X) /(\max X-\min X)$, where $x$ is the original value, and $y$ is the normalized value. For example, in terms of normalizing tourism intensity, the Cayman Islands received a standardized maximum score of 1 [(32-3)/(32-3)]. In similar fashion, the tourism density $[(7,951-292) /(36,088-292)]$ and tourism dependency $[(20-14) /(87-14)]$ scores are calculated and normalized. Subsequently, the normalized values of the different subindices are averaged to reach an overall composite overtourism index score. Due to data limitations and case sample constraints and based on previous studies (Kinseng et al., 2018), a nn-parametric test (Mann Whitney $U$ test with Fisher exact significance test) was conducted to identify the significant differences between sovereign and nonsovereign Caribbean SITEs.

\subsection{Analyzing regressors of overtourism}

To explore the formative structure of the overtourism construct, in addition to reducing the number of individual variables and the potential multicollinearity, a principal component regression (PCR) analysis - a special form of partial least square regression - was applied (Bair et al., 2006), in which the formative overtourism construct was regressed on the newly identified components. The small case sample size and data limitations precluded the use of structural equation modeling or path analysis. In PCR and consistent with previous studies

\section{Carribean overtourism}


IHR

35,1

28

(Li et al., 2018), instead of regressing the dependent variable, i.e. overtourism, on all the explanatory variables directly, the principal components of the explanatory variables are used as regressors. In applying PCR, there are three basic steps (Li et al., 2018), i.e. to conduct a principal component analysis of the individual variables, identify the validity and reliability parameters of the principal components and run a stepwise multivariate regression analysis on the valid components to identify the significant regressors. In examining the main antecedents of overtourism (see Propositions 1, 2 and 4), the applied PCR follows productionlike logic consisting of the different identified principal regressors (Du et al., 2016). The production function form is estimated as a log-linear relationship using $\ln (\mathrm{Y})=\mathrm{a} 0+$ $\sum$ ai $\ln (\mathrm{Ii})+\varepsilon$, with $Y=$ overtourism composite index, $I=$ antecedent factors (i.e. the PCR predictors) and $a=$ coefficients.

\section{Results}

4.1 How do sovereign and nonsovereign SITEs in the caribbean differ?

In examining the proposition that sovereign Caribbean SITEs experience significantly higher levels of overtourism, the findings indicate that there are significant differences between sovereign and nonsovereign SITEs (see Table 2). Caribbean nonsovereignties experience

\begin{tabular}{|c|c|c|c|c|}
\hline Indicators & $\begin{array}{l}\text { Sovereign } \\
\text { SITEs }\end{array}$ & $\begin{array}{l}\text { Nonsovereign } \\
\text { SITEs }\end{array}$ & Difference & Fisher exact significance $(p)$ \\
\hline $\begin{array}{l}\text { Tourism intensity (visitors per } \\
\text { capita) }\end{array}$ & 0.18 & 0.48 & 0.30 & $* * *$ \\
\hline Tourism density (visitors per $\mathrm{km}^{2}$ ) & 0.04 & 0.27 & 0.23 & $* *$ \\
\hline $\begin{array}{l}\text { Tourism dependency ( } \% \text { total } \\
\text { contribution to GDP) }\end{array}$ & 0.34 & 0.53 & 0.19 & $* *$ \\
\hline $\begin{array}{l}\text { Tourism export specialization ( } \% \\
\text { of total exports) }\end{array}$ & 0.48 & 0.62 & 0.14 & Ns \\
\hline $\begin{array}{l}\text { Tourism market share ( } \% \text { of } \\
\text { Caribbean tourism market) }\end{array}$ & 0.36 & 0.49 & 0.13 & Ns \\
\hline $\begin{array}{l}\text { Trade openness (total imports and } \\
\text { exports as } \% \text { of GDP) }\end{array}$ & 0.02 & 0.33 & 0.31 & $* * *$ \\
\hline $\begin{array}{l}\text { Resort density (number of hotel } \\
\text { rooms per } \mathrm{km}^{2} \text { ) }\end{array}$ & 0.22 & 0.43 & 0.21 & $* *$ \\
\hline $\begin{array}{l}\text { Resort style (average number of } \\
\text { rooms per resort) }\end{array}$ & 0.20 & 0.27 & 0.07 & Ns \\
\hline $\begin{array}{l}\text { Coastal resort density (number of } \\
\text { resorts per coastal km) }\end{array}$ & 0.20 & 0.32 & 0.12 & Ns \\
\hline $\begin{array}{l}\text { Coastal visitor density (number of } \\
\text { visitors per coastal } \mathrm{km} \text { ) }\end{array}$ & 0.08 & 0.25 & 0.17 & $* * *$ \\
\hline $\begin{array}{l}\text { Coastal pollution (construction } \\
\text { waste per coastal km) }\end{array}$ & 0.31 & 0.50 & 0.19 & $* *$ \\
\hline Coastal length $(\mathrm{km})$ & 0.39 & 0.13 & -0.26 & $* * *$ \\
\hline $\begin{array}{l}\text { Climate change impact (costs as \% } \\
\text { of GDP) }\end{array}$ & 0.51 & 0.25 & -0.26 & $* * *$ \\
\hline Airlift (number of airline flights) & 0.15 & 0.56 & 0.41 & $* * *$ \\
\hline $\begin{array}{l}\text { Cruise intensity (cruise to stay } \\
\text { over visitor ratio) }\end{array}$ & 0.24 & 0.31 & 0.07 & Ns \\
\hline $\begin{array}{l}\text { Population density (residents per } \\
\mathrm{km}^{2} \text { ) }\end{array}$ & 0.19 & 0.40 & 0.21 & $* * *$ \\
\hline $\begin{array}{l}\text { Foreign labor force (migrant labor } \\
\text { stock) }\end{array}$ & 0.13 & 0.58 & 0.45 & $* * *$ \\
\hline \multicolumn{5}{|c|}{ Note(s): $* * *(p<0.01)$ and $* *(p<0.05)$} \\
\hline
\end{tabular}

Table 2.

Stylized differences between sovereign and nonsovereign Caribbean SITEs

Note(s): $* * *(\phi<0.01)$ and $* *(\phi<0.05)$ 
higher levels of tourism intensity, density and dependency. Their trade openness and tourism specialization underscore a strong outward economic orientation, which is also corroborated by relatively more airlift and cruise calls. Demographically, nonsovereign SITEs have a larger migrant labor stock and population density ratio, largely due to tourism labor immigration and their sub-national jurisdictional status. Conversely, their coastal length is smaller with less coastal beach space. Consequently, coastal density levels for resorts, visitors and pollution are relatively greater in nonsovereign tourism dependencies. While not being significant, the cruise intensity and average resort size is slightly larger in nonsovereign SITEs due to the establishment of comparatively more international and larger resorts, as well as having more cruise calls.

In terms of climate change impact, nonsovereign SITEs are comparatively less prone to the costs of climate change when compared to sovereign SITEs. From a geopolitical perspective, nonsovereign SITEs may have access to finance and international assistance due to their subnational jurisdictional ties, and therefore more likely to absorb the costs of climate change (Baldacchino, 2006; Bertram, 2004; McElroy and Pearce, 2006). Alternatively, nonsovereign SITEs may be geographically dispersed and positioned on the peripheral of the Caribbean Hurricane belt, thereby reducing the direct exposure, risks and costs of extreme weather events. This would nurture the relatively uninterrupted and continuous expansion and growth of tourism. The findings indicate that climate change and tourism density are indeed negatively associated $(\beta=-0.14 ; p<0.05)$.

These results corroborate previous studies that nonsovereign Caribbean SITEs share a unique overtourism profile consisting of high tourism intensity, density and dependency levels; mature and expansive port and tourism infrastructures; large-scale beach front accommodations and international luxury chains; significant tourism promotion and tourism labor immigration and tourism-induced ecological stress with increasing social crowding especially in coastal zones (Budowski, 1976; Butler, 1980; Cohen, 1978; Dodds and Butler, 2019b; Doxey, 1978; Dunkel, 1984; Farrell and Runyan, 1991; Getz, 1983; Holder, 1988; Mathieson and Wall, 1982; McElroy, 2006; Wilkinson, 1989).

\subsection{What are the main antecedents and effects of overtourism in selected Caribbean SITES?}

An unrestrictive principal component analysis with Kaiser normalization and varimax rotation was conducted to identify the main constructs of overtourism. The analysis yielded five (5) components with satisfactory loadings ( $>0.60)$, acceptable adequacy (KMO $>0.68$; Bartlett's test of sphericity $<0.001$ ) and reliability (Cronbach $\alpha>0.70)$ for an exploratory study (see Table 3). Consistent with previous studies (Cole, 2007; Dodds and Butler, 2019b; McElroy, 2006), the findings indicate that the status of overtourism component incorporates tourism intensity, tourism density and tourism dependency, reflecting the volume, concentration and contribution of tourism, respectively.

Based on the (unweighted) average of tourism intensity, density and dependency subindices, a general overtourism index was calculated (see Table 4 for sub-indices). The average overtourism index demonstrates that the propensity for overtourism is relatively higher in nonsovereign SITEs, i.e. St. Maarten, Aruba, Cayman Islands, British Virgin Islands, Anguilla and the US Virgin Islands, which indeed share a unique and significantly different overtourism profile (Chi-square $=7.27$ and $p<0.01$ ), despite individual destination niche differences (see Table 4). These islands represent Dutch, British and US nonsovereign Caribbean SITEs. These results support the proposition that sovereign Caribbean SITEs experience significantly higher levels of overtourism.

Based on the results of the principal component analysis, three independent constructs antecedents of overtourism - were identified, i.e. tourism supply chain, tourism architectural style and tourism export specialization. Whereas the tourism supply chain component describes the supply chain effect of the growth in airlift, accommodations and labor, the

\section{Carribean overtourism}




\begin{tabular}{|c|c|c|c|c|c|c|}
\hline $\begin{array}{l}\mathrm{IHR} \\
35,1\end{array}$ & $\begin{array}{l}\text { Explanatory } \\
\text { variables }\end{array}$ & $\begin{array}{c}\text { 1. Overtourism } \\
\text { status }\end{array}$ & $\begin{array}{l}\text { 2. Tourism } \\
\text { ecological } \\
\text { stress }\end{array}$ & $\begin{array}{l}\text { Components } \\
\text { 3. Tourism } \\
\text { supply } \\
\text { chain }\end{array}$ & $\begin{array}{l}\text { 4. Tourism } \\
\text { infrastructure }\end{array}$ & $\begin{array}{l}\text { 5. Tourism } \\
\text { export } \\
\text { specialization }\end{array}$ \\
\hline \multirow{16}{*}{30} & $\begin{array}{l}\text { Tourism } \\
\text { intensity }\end{array}$ & 0.85 & & & & \\
\hline & Tourism density & 0.86 & & & & \\
\hline & $\begin{array}{l}\text { Tourism } \\
\text { dependency }\end{array}$ & 0.68 & & & & \\
\hline & $\begin{array}{l}\text { Coastal resort } \\
\text { stress }\end{array}$ & & 0.96 & & & \\
\hline & $\begin{array}{l}\text { Coastal visitor } \\
\text { stress }\end{array}$ & & 0.93 & & & \\
\hline & Coastal pollution & & 0.85 & & & \\
\hline & Resort density & & & 0.89 & & \\
\hline & Airlift & & & 0.92 & & \\
\hline & Migrant stock & & & 0.81 & & \\
\hline & Cruise intensity & & & & 0.91 & \\
\hline & Resort style & & & & 0.89 & \\
\hline & Coastal length & & & & 0.61 & \\
\hline & $\begin{array}{l}\text { Tourism export } \\
\text { specialization }\end{array}$ & & & & & 0.91 \\
\hline & Trade openness & & & & & 0.86 \\
\hline & Eigenvalue & 7.11 & 2.36 & 2.06 & 1.5 & 1.08 \\
\hline & $\begin{array}{l}\text { Variance } \\
\text { (cumulative \%) }\end{array}$ & 44.5 & 59.3 & 72.1 & 81.5 & 88.2 \\
\hline $\begin{array}{l}\text { Table } 3 \text {. } \\
\text { Results of principal } \\
\text { component analysis }\end{array}$ & $\begin{array}{l}\text { Internal } \\
\text { consistency } \\
(\text { Cronbach } \alpha \text { ) }\end{array}$ & 0.71 & 0.89 & 0.84 & 0.73 & 0.79 \\
\hline
\end{tabular}

tourism infrastructure component describes the spatial concentration and design of cruise and accommodation infrastructures in a specific geographic area or coastal zone. The tourism export specialization component describes the outward (export-led) economic orientation and tourism specialization focused on, e.g. tourism investments and expansion, export earnings and revenues and promotion. The tourism ecological stress component consists of coastal resort stress, coastal visitor stress and coastal pollution and is an indirect effect of overtourism. It describes the stressors and pressures from land- and marine-based tourism activities in (concentrated) coastal areas, which are conducive to ecological decay and coastal erosion (Duval, 2004; Ewing-Chow, 2019; Gossling, 2002; Hunter and Shaw, 2007; Marsiglio, 2018; McElroy, 2006; Williams and Ponsford, 2008).

The findings also indicated that several variables had insufficient factor loadings $(<0.60)$ and were therefore disregarded and excluded from further analysis. These variables include relative tourism market share and population density and are both considered structural features of destination size (McElroy, 2006).

To examine Proposition 1, 2, and 4, regression analysis was conducted on the previously identified components to assess the relationship between the state of overtourism, tourism ecological stress and labor force participation. Due to the hypothesized nonlinear nature of tourism development (Butler, 1980; Farrell and Twining-Ward, 2004), a quadratic multivariate regression analysis was applied. The findings (see Table 5) indicate that a quadratic function has superior fit $(F$-test $=11.41$ and $p<0.001)$ with an adjusted $R^{2}$ of 0.64 and a significant curve-linear relationship $(\phi<0.01)$ between the state of overtourism and tourism ecological stress $\left(\beta_{2}=0.96\right.$ and $\left.\beta_{1}=0.02\right)$. 


\begin{tabular}{|c|c|c|c|c|c|c|}
\hline $\begin{array}{l}\text { Selected } \\
\text { SITEs }\end{array}$ & Sovereignty* & $\begin{array}{c}\text { Tourism } \\
\text { intensity index } \\
\text { (total visitors } \\
\text { per capita) }\end{array}$ & $\begin{array}{c}\text { Tourism } \\
\text { density index } \\
\text { (visitors per } \\
\mathrm{km}^{2} \text { ) }\end{array}$ & $\begin{array}{c}\text { Tourism } \\
\text { dependency } \\
\text { index (tourism-to- } \\
\text { GDP) }\end{array}$ & $\begin{array}{l}\text { Overtourism } \\
\text { index (average of } \\
\text { sub-indices) }\end{array}$ & $\begin{array}{l}\text { Carribean } \\
\text { overtourism }\end{array}$ \\
\hline St. Maarten & $\mathrm{N}$ & 0.89 & 1.00 & 0.88 & 0.92 & \\
\hline Aruba & $\mathrm{N}$ & 0.48 & 0.29 & 1.00 & 0.59 & \\
\hline $\begin{array}{l}\text { Cayman } \\
\text { Islands }\end{array}$ & $\mathrm{N}$ & 1.00 & 0.21 & 0.22 & 0.48 & 31 \\
\hline $\begin{array}{l}\text { British Virgin } \\
\text { Islands }\end{array}$ & $\mathrm{N}$ & 0.43 & 0.08 & 0.77 & 0.43 & \\
\hline Anguilla & $\mathrm{N}$ & 0.41 & 0.06 & 0.66 & 0.38 & \\
\hline $\begin{array}{l}\text { US Virgin } \\
\text { Islands }\end{array}$ & $\mathrm{N}$ & 0.39 & 0.11 & 0.62 & 0.37 & \\
\hline $\begin{array}{l}\text { St. Kitts and } \\
\text { Nevis }\end{array}$ & $\mathrm{S}$ & 0.61 & 0.11 & 0.18 & 0.30 & \\
\hline $\begin{array}{l}\text { Antigua and } \\
\text { Barbuda }\end{array}$ & $\mathrm{S}$ & 0.24 & 0.05 & 0.52 & 0.27 & \\
\hline Bahamas & $\mathrm{S}$ & 0.27 & 0.00 & 0.47 & 0.25 & \\
\hline Bermuda & $\mathrm{N}$ & 0.28 & 0.40 & 0.05 & 0.24 & \\
\hline St. Lucia & $\mathrm{S}$ & 0.09 & 0.04 & 0.39 & 0.17 & \\
\hline Barbados & $\mathrm{S}$ & 0.07 & 0.08 & 0.37 & 0.17 & \\
\hline $\begin{array}{l}\text { St. Vincent } \\
\text { and the } \\
\text { Grenadines }\end{array}$ & $\mathrm{S}$ & 0.00 & 0.01 & 0.44 & 0.15 & \\
\hline Dominica & $\mathrm{S}$ & 0.13 & 0.01 & 0.27 & 0.14 & \\
\hline Grenada & $\mathrm{S}$ & 0.05 & 0.03 & 0.13 & 0.07 & \\
\hline Martinique & $\mathrm{N}$ & 0.01 & 0.02 & 0.00 & 0.01 & \\
\hline Overall average & & 0.33 & 0.15 & 0.43 & 0.30 & \\
\hline Average non-so & vereign SITEs & 0.49 & 0.27 & 0.53 & 0.43 & Overtourism in \\
\hline Average soverei & ign SITEs & 0.18 & 0.04 & 0.34 & 0.19 & selected SITEs in the \\
\hline \multicolumn{6}{|c|}{ Note(s): *N: nonsovereign island state; S: sovereign island state } & Caribbean \\
\hline
\end{tabular}

\begin{tabular}{lcccr}
\hline & \multicolumn{3}{c}{ Independent component: overtourism state } & \\
Dependent variables & Coefficient $(\beta)$ & Adjusted $R^{2}$ & Significance $(\phi)$ & \\
Real GDP growth & -5.28 & 0.39 & $*$ & \\
Output volatility & 0.84 & 0.23 & $* *$ & Table 5. \\
Labor force participation & -2.14 & 0.29 & $* *$ & Direct and indirect \\
Ecological stress & 0.96 & 0.64 & & effects of overtourism \\
in selected \\
Note $(\mathbf{s}): * *(p<0.01)$ and $*(\phi<0.05)$ & & & Caribbean SITEs \\
\hline
\end{tabular}

This concave relationship indicates that as the intensity and density of tourism increases, the ecological pressures grow and, more importantly, accelerate after exceeding a critical threshold, as measured by the inflection point. This underscores a tourism overshoot beyond the natural absorptive capacity of the local ecology, which generates negative pressures on real GDP growth in the long run. Furthermore, this adverse impact is compounded by the negative (nonlinear) effects of climate change $\left(\beta_{2}=-0.75\right.$; adjusted $R^{2}=0.28 ; p<0.10$ ) on the real output. These results provide support for proposition that higher levels of overtourism in Caribbean SITEs are positively associated with relatively more ecological stress (Proposition 1).

In terms of the labor market impact, the results of the quadratic regression analysis indicate that overtourism has a negative (curve-linear) effect on labor force participation 
IHR

35,1

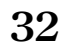

$\left(\beta_{2}=-2.14\right.$; adjusted $\left.R^{2}=0.29 ; p<0.05\right)$, which depicts a tourism overrun and exhaustion of the domestic labor market and tourism workforce capacity. Further analysis indicates that overtourism has a negative (curve-linear) effect on real GDP growth between 1995 and 2018 $\left(\beta_{2}=-5.28\right.$; adjusted $\left.R^{2}=0.39 ; p<0.05\right)$ and is a significant source of output volatility - as measured by the output variance - in selected Caribbean SITEs $\left(\beta=0.84\right.$; adjusted $R^{2}=0.23$; $p<0.05)$. The results suggest that beyond a certain optimum state of tourism intensity, density and dependency, there is an exponentially adverse effect on the socioecology of selected Caribbean SITEs, including Anguilla, Aruba, British Virgin Islands, Cayman Islands, St. Maarten and the US Virgin Islands. These findings provide support for proposition that higher levels of overtourism in Caribbean SITEs are positively associated with relatively lower labor force participation and higher economic volatility (Proposition 1). Moreover, the results indicate that the impact of overtourism in Caribbean SITEs is transmitted through both direct as well as indirect channels (Proposition 2).

Turning toward to the antecedents of overtourism (see Table 6), the results indicate that three supply-oriented components influence the state of overtourism (adjusted $R^{2}=0.81$; $p<0.05)$. A significant association is found for tourism supply chain $(\beta=0.47 ; p<0.01)$. Likewise, tourism infrastructure $(\beta=0.30 ; p<0.05)$ and tourism export specialization $(\beta=0.25 ; p<0.05)$ show significant positive relationships with the state of overtourism. From an international tourism demand-based perspective, the relative tourism market share (in the Caribbean) has a significant positive effect on the state of overtourism $(\beta=0.26$; $p<0.05)$. Although the tourism supply chain effect shows a relatively stronger association, the findings indicate that there is no single factor that determines the extent or state of overtourism. Rather, it is a combination of mutually reinforcing supply and demand conditions and the multiplicative forces that shape the state of overtourism in selected Caribbean SITEs. These results provide support for proposition that higher levels of overtourism in Caribbean SITEs are positively associated with both international tourism demand and supply factors (Proposition 4).

\section{Discussion}

In reviewing the overall findings of this study, the general results corroborate previous research (Acevedo et al., 2017; Baldacchino, 2006; Bishop, 2010; Capocchi et al., 2019; Dodds and Butler, 2019b; Duval, 2004; Joppe, 2019; McElroy, 2006; Scheyvens and Biddulph, 2017; Richter, 1994; Williams and Ponsford, 2008) and support the research propositions (see Table 7). More specifically, the research indicates that there are significant differences between sovereign and nonsovereign SITEs in the Caribbean.

Nonsovereign SITEs are more likely to experience a higher propensity for overtourism and the adverse effects and risks thereof. Their longstanding outward economic growth orientation is geared at increasing tourism exports and fostering tourism investments, with a constant focus on expanding airlift, cruise calls and related tourism infrastructures and

Table 6.

Antecedents of overtourism in selected Caribbean SITEs

\begin{tabular}{lccc}
\hline & \multicolumn{3}{c}{ Dependent component: overtourism state } \\
Independent components & Coefficient $(\beta)$ & $t$-test & Significance \\
\hline Tourism supply & 0.47 & 4.89 & $* *$ \\
Tourism style & 0.30 & 2.41 & $*$ \\
Tourism specialization & 0.25 & 2.21 & $*$ \\
Tourism market share & 0.26 & 2.24 & $*$ \\
Adjusted $R^{2}$ & 0.81 & &
\end{tabular}

$\operatorname{Note}(\mathbf{s}): * *(p<0.01)$ and $*(p<0.05)$ 


\begin{tabular}{|c|c|c|c|}
\hline Proposition & Support & Reference studies and theories & \\
\hline $\begin{array}{l}\text { In comparison to nonsovereign Caribbean } \\
\text { SITEs, sovereign Caribbean SITEs experience } \\
\text { significantly higher levels of overtourism }\end{array}$ & Support & $\begin{array}{l}\text { Baldacchino (2006), Bertram (2004), Cole (2007) } \\
\text { and McElroy (2003) }\end{array}$ & \\
\hline $\begin{array}{l}\text { The impact of overtourism in Caribbean SITEs is } \\
\text { transmitted through both direct channels as well } \\
\text { as indirect channels }\end{array}$ & Support & $\begin{array}{l}\text { Capocchi et al. (2019), Crandall (1994), Dodds } \\
\text { and Butler (2019b), Joppe (2019) and Koens } \\
\text { et al. (2018) }\end{array}$ & \\
\hline $\begin{array}{l}\text { Higher levels of overtourism in Caribbean SITEs } \\
\text { are positively associated with, lower labor force } \\
\text { participation, more ecological stress and higher } \\
\text { economic volatility }\end{array}$ & Support & $\begin{array}{l}\text { Bishop (2010), Butler (1980), Dodds and Butler } \\
\text { (2019b), Farrell and Runyan (1991), Gupta and } \\
\text { Vegeling (2016), Joppe (2019), Marsiglio (2018), } \\
\text { Meier (2001), Raworth (2017), Richter (1994) } \\
\text { and Scheyvens and Biddulph (2017) }\end{array}$ & \\
\hline $\begin{array}{l}\text { Higher levels of overtourism are associated with } \\
\text { both international tourism demand as well as } \\
\text { interdependent tourism supply factors }\end{array}$ & Support & $\begin{array}{l}\text { Acevedo et al. (2017), Cole (2007), Dodds and } \\
\text { Butler (2019b) and Joppe (2019) }\end{array}$ & $\begin{array}{r}\text { Table } 7 . \\
\text { Support for research } \\
\text { propositions }\end{array}$ \\
\hline
\end{tabular}

services. These progrowth tourism policies usually entail numerous fiscal and economic incentives, including e.g. tax holidays, government guarantees and special concessions for international tourism investors and contractors. Furthermore, the private tourism sector is actively involved in the shaping of tourism policies and is an (in)direct beneficiary of tourism (tax) revenues.

The tourism infrastructure in nonsovereign SITEs is mainly characterized by large scale and international chain resorts, which are mostly concentrated in coastal areas. In addition, nonsovereign SITEs enjoy frequent cruise calls and experience higher cruise intensity levels. Their past tourism achievements have been rewarded with numerous destination marketing and branding awards, and they enjoy a relatively popular reputation among visitors, which reinforces further tourism intensity and export specialization.

Their subsequent demographic development is characterized by a comparatively large migrant labor stock and high population density, mainly due to tourism labor immigration stemming primarily from the increasing specialization in and style of tourism. The confluence of these factors generates higher coastal density levels and environmental pollution in nonsovereign tourism dependencies. Although not immune to the gradual "slow-burn" effects of global warming and sea level rise, nonsovereign SITEs are also comparatively less prone to the costs of extreme weather events when compared to sovereign SITEs.

These findings support previous studies that demonstrate an aggregate effect of multiple economic forces that shape and generate overtourism over time and space (Cole, 2007; Dodds and Butler, 2019b; Joppe, 2019; McElroy, 2006). More specifically, the results indicate that there are three main factors that engender a state of overtourism. These supply-driven factors are tourism export specialization, tourism supply chain and tourism infrastructure style. Furthermore, the propensity for overtourism is also influenced by international tourism demand and relative tourism market share. Thus, both tourism supply and tourism demand actively influence and shape the evolution of overtourism in select Caribbean SITEs; hence, supporting this study's proposition that both international tourism demand as well as tourism supply affect the propensity for overtourism in Caribbean SITEs.

In terms of the effects of overtourism in select Caribbean SITEs, the findings indicate that the state of overtourism has an adverse impact on environmental and social conditions, as well as fueling relatively lower and more volatile economic growth. These findings support previous studies that indicate that social, ecological and economic impacts of overtourism are likely to coalesce (Budowski, 1976; Cole, 2007; Dodds and Butler, 2019b; Duval, 2004; Farrell and Twinning-Ward, 2004; Joppe, 2019; Mathieson and Wall, 1982; Marsiglio, 2018; 
IHR

35,1

McElroy, 2006; Scheyvens and Biddulph, 2017). With regard to the quality of the environment, overtourism is positively associated with increased ecological pressures and stress due to the high concentration and density of (large) resorts and visitor hordes in specific coastal areas and delicate ecological zones. These negative environmental impacts accelerate exponentially over time upon exceeding local ecological absorptive capacities and surpass the ecological boundaries of Caribbean SITEs (Farrell and Runyan, 1991; Marsiglio, 2018; Raworth, 2017; Williams and Ponsford, 2008).

With reference to social conditions, overtourism produces significant pressures on the local labor market, thereby generating a surge in labor demand and the subsequent influx of substantial foreign labor immigration, which bring about considerable urbanization and increased population density, thus generating increasing levels of crowding and congestion in coastal areas. In the long run, the rise in the labor force is conducive to downside pressures on income equality and labor force participation in addition to eroding social capital (Bishop, 2010; Raworth, 2017; Richter, 1994; McElroy, 2006). Furthermore, decreasing levels of labor force participation can generate significant pressures on social costs and government expenditures (Dodds and Butler, 2019b).

From an economic perspective, the findings indicate that the state of overtourism has an adverse effect on economic stability due to several interrelated factors, including diminishing real GDP growth rates and increased output volatility. The results support previous studies and suggest that if persistent, these adverse conditions create downward pressures on real GDP per capita growth and abate economic well-being in the long run. This negative effect is, furthermore, exacerbated by the exhaustion of socioecological qualities in addition to accelerating climate change impacts.

\section{Conclusions}

This study explored the state, antecedents and effects of overtourism in sovereign and nonsovereign SITEs in the Caribbean. The aim of the exploratory research was to identify the differentiating overtourism qualities between sovereign and nonsovereign Caribbean SITEs and, subsequently, to examine the driving factors and impacts of overtourism in the Caribbean.

In terms of the first research question - how do sovereign and nonsovereign SITEs in the Caribbean differ? - the results indicate that (selected) Caribbean dependencies have a unique tourism profile that is relatively more conducive to overtourism. While politically and culturally diverse, these nonsovereign SITEs share several common features, including higher intensity, density and dependency levels on tourism service exports. They have a strong outward orientation toward trade and tourism specialization, which results in significantly more airlift and cruise calls, and relatively larger tourism market share in the Caribbean.

The expansive progrowth tourism policies in Caribbean dependencies are also conducive to more tourism labor immigration and higher population density, especially in coastal zones. Due to their relatively smaller coastal length and less beach space, in addition to relatively less (frequent and intense) extreme weather conditions, nonsovereign Caribbean SITEs also experience a higher density of (large-scale) coastal resorts, more beach visitors and amenities and the commensurate ecological pressures and environmental pollution that follow suit.

With reference to the second question - what are the main drivers and impacts of overtourism in select Caribbean SITES? - the conclusions show that overtourism is shaped by both tourism supply and tourism demand forces, involving a combination of tourism export specialization, tourism supply chain and tourism architectural style. Conversely, international tourism demand and market share also influence the state of overtourism. Due to the dynamic, multifaceted and path dependent nature of overtourism, the adverse 
externalities and impacts are experienced across social and ecological dimensions as well as economic stability. In addition to generating social inequality and environmental decay, overtourism also engenders diminishing real GDP growth and significant output volatility.

These results support the theoretical assumptions of development economics and previous political economic tourism studies in the Caribbean. More specifically, the findings confirm the adverse economic, social and environmental impacts of uncontrolled tourism growth and the potential societal backlash that may follow against tourism and visitors. By focusing exclusively and systematically on the (rapid) pace of tourism expansion for shortterm gains rather than the pattern and productivity of tourism development for the long run, overtourism spurs extractive and noninclusive growth.

Although restricted to an exploratory study of selected Caribbean SITEs, the findings of this investigation provide a theoretical expansion and empirically enriched framing of the overtourism concept, including the antecedents and effects of overtourism and the dynamic interrelationships. By employing a political economic lens on the prominence of overtourism in Caribbean SITEs, the findings of this study contribute to a relatively more contextualized framing of the complexity and dynamics of overtourism, especially within the context of small island tourism politics and politicking. This conceptual model of overtourism provides several avenues for future research, including, but not limited to, the application and validation of the model in large(r) Caribbean and nonCaribbean SITEs and continental cities and metropolitan areas. Moreover, contingent upon available data, the application of econometric analysis, such as structural equation modeling or path analysis would provide further empirical scrutiny. Likewise, future studies should aim to incorporate larger and more complete datasets for hypothesis modeling and testing.

Alternatively, in-depth case studies could be conducted with a specific emphasis on the market and institutional forces that shape overtourism over time, thereby providing a more qualitative and politically enriched understanding of overtourism in the Caribbean future research which is also required to assess and quantify the total costs of overtourism in Caribbean SITEs, especially from a future oriented perspective. Simulation and scenario studies are highly recommended to build robust and future-proof evidence-based policies for mitigating and adapting to the risks of overtourism and climate change. More importantly, future studies should explore and assess the effectiveness of different tourism policy measures and tourism governance mechanisms for mitigating the risks of overtourism and adapting tourism systems in SITEs.

Acknowledging the exploratory nature and the delimitations of this study, the findings hold several policy implications for strengthening the resilience of Caribbean SITEs in the wake of the COVID-19 pandemic and other structural vulnerabilities, such as climate change. First and foremost, the findings testify to the contextual and dynamic nature of overtourism and more importantly to the need to address social and ecological developments explicitly, extensively and urgently in economic policies and institutional arrangements, especially in nonsovereign and tourism-dependent small island economies in the Caribbean. From a tourism policy measurement perspective and in line with the principles of sustainable tourism, Caribbean tourism authorities should adopt noneconomic measures of tourism growth and development. More importantly, social, labor, educational and environmental data compilation and analysis should be integral to the governance of tourism, especially in Caribbean SITEs, which are significantly more at risk from the negative externalities of relentless tourism growth in a small open economy. Including a more balanced mix of tourism impact measures would also provide an important feedback and feed forward loop to future tourism developments. Moreover, the responsible and related diversification of these political tourism economies would also benefit less volatile economic growth.

Furthermore, the results indicate that in the absence of structural reforms and policy reorientations, including. labor market reforms, targeted social and education programs,

\section{Carribean overtourism}


IHR

35,1

environmental and urbanization policies and regulatory enforcement, the state of overtourism generates lower labor force participation, uneven income distribution and stagnant workforce development, in addition to rising environmental degradation and coastal erosion. To foster more inclusive and responsible forms of tourism and mitigate the risks of overtourism, Caribbean tourism authorities would benefit significantly from expanding the time horizons of current and future tourism developments by considering long-term developments in, e.g. social demographics, the labor force and economic well-being. Consideration should be given to strengthening labor force participation and equality, particularly of younger professionals. Likewise, to limit the adverse effects of overtourism, the enforcement of prudent tourism and environmental regulations is recommended, including the use and application of (geographic) zoning rules and maintaining capacity limits for fragile ecological areas. In addition, it is fundamental that the pacing of tourism development is incorporated in medium to long-term development.

In the long run, overtourism fuels diminishing economic growth and increasing economic volatility. Rather than simply devising buffers for absorbing shocks and bouncing back to previous dependent paths of stagnant economic growth, fostering 21st century resilience of Caribbean SITEs requires building innovation and institutional capabilities to anticipate shocks, to adapt and learn, and bounce forward toward new paths of development. Thereto, it is essential that Caribbean tourism destinations build and extend their collaborative platforms with multiple stakeholders, including social and environmental agencies and nongovernmental organizations. More critically, tourism governance matters, and the ability to govern judiciously matters even more in Caribbean SITEs that are now experiencing an unprecedented economic crisis in the wake of the global health pandemic.

\section{References}

Acemoglu, D. and Robinson, J.A. (2012), Why Nations Fail: The Origins of Power, Prosperity and Poverty, Crown, New York.

Acevedo, S., LaFramboise, N., Wong, J., Alleyne, T., Otker, I., Ramakrishnan, U. and Srinivasan, K. (2017), "Caribbean tourism in the global marketplace: trends, drivers, and challenges", in IMF (Ed.), Unleashing Growth and Strengthening Resilience in the Caribbean, (2017), IMF Publications, Washington DC.

Armstrong, H.W. and Read, R. (2000), "Comparing the economic performance of dependent territories and sovereign micro-states", Economic Development and Cultural Change, Vol. 48 No. 2, pp. 285-306.

Bair, E., Hastie, T., Debashis, P. and Tibshirani, R. (2006), "Prediction by supervised principal components", Journal of the American Statistical Association, Vol. 101 No. 473, pp. 119-137, doi: $10.1198 / 016214505000000628$.

Baldacchino, G. (2006), "Small islands versus big cities: lessons in the political economy of small islands", Journal of Technology Transfer, Vol. 31 No. 1, pp. 91-100.

Bertram, G. (2004), "On the convergence of small island economies with their metropolitan patrons", World Development, Vol. 32 No. 2, pp. 343-364.

Bishop, M.L. (2010), "Tourism as a small-state development strategy: pier pressure in the Eastern Caribbean?', Progress in Development Studies, Vol. 10 No. 2, pp. 99-114.

Brautigam, D. and Woolcock, M. (2001), Small States in a Global Economy, Discussion paper No. 2001/37, United Nations UniversityFinland, Helsinki.

Brida, J.G., Cortes-Jimenez, I. and Pulina, M. (2016), "Has the tourism-led growth hypothesis been validated? A literature review", Current Issues in Tourism, Vol. 19 No. 5, pp. 394-430, doi: 10. 1080/13683500.2013.868414.

Briguglio, L., Archer, B., Jafari, J. and Wall, G. (1996), Sustainable Tourism in Islands and Smalls States: Issues and Policies, Pinter, London. 
Britell, A. (2020), Dominican Republic, Cuba Leading Caribbean Hotel Boom, available at: https://www. caribjournal.com/2020/02/19/dominican-republic-cuba-caribbean-hotel-boom/ (accessed 20 February 2020).

Budowski, G. (1976), “Tourism and environmental conservation: conflict, coexistence, or symbiosis?", Environmental Conservation, Vol. 3 No. 1, pp. 27-31.

Butler, R. (1980), "The concept of a tourism area cycle of evolution: implications for management of resources", Canadian Geographer, Vol. 24 No. 1, pp. 5-12.

Cannonier, C. and Galloway, M. (2019), "The economic growth and impact of tourism in small island developing states - evidence from the caribbean”, Tourism Economics, Vol. 25 No. 1, pp. 85-108.

Capocchi, V., Pierotti and Amaduzzi (2019), "Overtourism: a literature review to assess implications and future perspectives", Sustainability, Vol. 11, p. 3303, available at: https://www.researchgate. net/publication/333818256_Overtourism_A_Literature_Review_to_Assess_Implications_and_ Future_Perspectives (accessed 3 October 2019).

Caribbean Tourism Organization (2020), State of the Tourism Industry 2019, available at: https:// www.onecaribbean.org/statistics/annual-reviews-prospects/ (accessed 10 July 2020).

Caribbean Tourism Organization (CTO) (2019a), Annual Statistics Report, available at: https:/www. onecaribbean.org/buy-cto-tourism-statistics/annual-statistical-report/ (accessed 19 November 2020).

Caribbean Tourism Organization (2019b), Caribbean Pushes for Inclusive Tourism Development, available at: https://www.onecaribbean.org/caribbean-pushes-for-inclusive-tourismdevelopment/ (accessed 3 March 2020).

Center for Responsible Travel (CREST) (2018), The Case for Responsible Travel: Trends and Statistics 2018, available at: https:/www.responsibletravel.org/docs/ The_Case_for_Responsible_ Travel_2018_FINAL_FOR_WEB.pdf (accessed 2 June 2019).

Chamon, M., Charap, J., Chen, Q., Leigh, D., Alleyne, T., Otker, I., Ramakrishnan, U. and Srinivasan, K. (2017), "Reinvigorating growth in the caribbean", in IMF (Ed.), Unleashing Growth and Strengthening Resilience in the Caribbean, 2017, IMF Publications, Washington DC.

Cohen, E. (1978), "Impact of tourism on the physical environment", Annals of Tourism Research, Vol. 5 No. 2, pp. 215-237.

Cole, S. (2007), "Beyond the resort life Cycle: the micro-dynamics of destination tourism", Tourism and Regional Science, Vol. 37 No. 3, pp. 266-278.

Cowen, M.P. and Shenton, R.W. (1996), Doctrines of Development, Routledge, London.

Crandall, L. (1994), "The social impact of tourism on developing regions and its measurement", in Ritchie, J.R.B. and Goeldner, C.R. (Eds), Travel, Tourism and Hospitality Research. A Handbook for Managers and Researchers, 2nd ed., John Wiley and Sons, Canada.

Croes, R. (2006), "A paradigm shift to a new strategy for small island economies: embracing demand side economics for value enhancement and long-term economic stability", Tourism Management, Vol. 27 No. 3, pp. 453-465.

Croes, R., Ridderstaat, J., Bak, M. and Zientara, P. (2021), "Tourism specialization, economic growth, human development and transition economies: the case of Poland", Tourism Management, available at: https://www.sciencedirect.com/science/article/pii/S0261517720301072?via\%3Dihub (accessed 7 October 2020).

Daye, M., Chambers, D. and Roberts, S. (2008), New Perspectives in Caribbean Tourism, Routledge, New York/London.

Dehoorne, O., Murat, C. and Petit-Charles, N. (2010), "International tourism in the caribbean area: Current status and future prospects”, Études Caribéennes, available at: https://journals. openedition.org/etudescaribeennes/4713?lang =en (accessed 8 February 2012).

Dodds, R. and Butler, R.W. (2019a), "The phenomena of overtourism: a review”, International Journal of Tourism Cities, Vol. 5 No. 4, pp. 519-528.

\section{Carribean overtourism}


IHR

35,1
Dodds, R. and Butler, R.W. (2019b), Overtourism: Issues, Realities and Solutions, De Gruyter Studies in Tourism, Walter de Gruyter, Berlin.

Doxey, G. (1978), "A causation theory of visitor-resident irritants: methodology and research inferences", The Impact of Tourism, the Sixth Annual Conference Proceedings, The Travel Research Association, San Diego, pp. 195-198.

Du, D., Lew, A. and Ng, P. (2016), “Tourism and economic growth”, Journal of Travel Research, Vol. 55, pp. 454-464, doi: 10.1177/0047287514563167.

Dunkel, D.R. (1984), "Tourism and the environment: a review of the literature and issues", Environmental Sociology, Vol. 37, pp. 5-18.

Duval, D.T. (Ed.) (2004), Tourism in the Caribbean. Trends, Development, Prospects, Routledge, London.

Ewing-Chow, D. (2019), The Environmental Impact of Caribbean Tourism Undermines its Economic Benefit, Forbes, available at: https://www.forbes.com/sites/daphneewingchow/2019/11/26/thecarbon-footprint-of-caribbean-tourism-undermines-its-economic-benefit/\#70d1ebb93cb5 (accessed 26 November 2019).

Farrell, B. and Runyan, D. (1991), "Ecology and tourism”, Annals of Tourism Research, Vol. 18, pp. 26-40.

Farrell, B. and Twinning-Ward (2004), "Reconceptualizing tourism", Annals of Tourism Research, Vol. 31 No. 2, pp. 274-295.

Getz, D. (1983), "Capacity to absorb tourism: Concepts and implications or strategic planning”, Annals of Tourism Research, Vol. 10 No. 2, pp. 239-263.

Goodwin, H. (2017), "The challenge of overtourism", Responsible Tourism Partnership Working Paper 4. October, 2017, available at: https://haroldgoodwin.info/wp-content/uploads/2020/08/ rtpwp4overtourism012017.pdf.

Gossling, S. (2002), "Global environmental consequences of tourism”, Global Environmental Change, Vol. 12 No. 4, pp. 283-302.

Gupta, J. and Vegeling, C. (2016), "Sustainable development goals and inclusive development", International Environmental Agreements, Vol. 16, pp. 433-448.

Hall, C.M. and Williams, A.M. (2008), Tourism and Innovation, Routledge, Oxon.

Holder, J. (1988), "Pattern and impact of tourism on the environment of the Caribbean", Tourism Management, Vol. 9 No. 2, pp. 119-227.

Hunter, C. and Shaw, J. (2007), "The ecological footprint as key indicator of sustainable tourism", Tourism Management, Vol. 28, pp. 46-57.

Ianchovichina, E. and Lundstrom, S. (2009), Inclusive Growth Analytics: Framework and Application, Policy Research Working Paper, No. 4851, World Bank, Washington, DC.

International Monetary Fund (IMF) (2019), Building Resilience in Developing Countries Vulnerable to Large Natural Disasters, available at: https://www.imf.org/en/Publications/Policy-Papers/ Issues/2019/06/24/Building-Resilience-in-Developing-Countries-Vulnerable-to-Large-NaturalDisasters-47020 (accessed 25 August 2015).

International Monetary Fund (IMF) (2020), Tourism Trauma and COVID-19, available at: https:// blogs.imf.org/2020/08/20/tourism-trauma-and-covid-19/ (accessed 7 September 2020).

Island Resource Foundation (1996), Tourism and Coastal Resources Degradation in the Wider Caribbean, St. Thomas, Virgin Island.

Joppe, M. (2019), "The roles of policy, planning, and governance in preventing and managing overtourism", in Dodds, R. and Butler, R.W. (Eds), Overtourism: Issues, Realities and Solutions, De Gruyter Studies in Tourism, De Gruyter, Oldenbourg.

Kinseng, R.A., Nasdian, F.E., Fatchiya, A., Mahmud, A. and Stanford, R.J. (2018), "Marine-tourism development on a small island in Indonesia: blessing or curse?", Asia Pacific Journal of Tourism Research, Vol. 23 No. 11, pp. 1062-1072, doi: 10.1080/10941665.2018.1515781. 
Koens, K., Postma, A. and Papp, B. (2018), "Is Overtourism overused? Understanding the impact of tourism in a city context", Sustainability, Vol. 10, p. 4384.

Kohr, L. (1977), The Overdeveloped Nations: The Diseconomies of Scale, Christopher Davies Publishers, Swansea.

Leigh, D., Srinivasan, K., Werner, A., Alleyne, T., Otker, I., Ramakrishnan, U. and Srinivasan, K. (2017), "Unleashing strong, sustainable, and inclusive growth in the Caribbean", in IMF (Ed.), Unleashing Growth and Strengthening Resilience in the Caribbean, (2017), IMF Publications, Washington DC.

Li, Y., Zhang, Y. and Liu, T. (2018), "Analysis of principal Component regression equations of air transportation and local economy: taking tianjin as an example", Theoretical Economics Letters, Vol. 8, pp. 1830-1839, doi: 10.4236/tel.2018.810120.

Marsiglio, S. (2017), "On the carrying capacity and the optimal number of visitors in tourism destinations", Tourism Economics, Vol. 23 No. 3, pp. 632-646.

Marsiglio, S. (2018), "On the implications of tourism specialization and structural change in tourism destinations", Tourism Economics: The Business and Finance of Tourism and Recreation, Vol. 24 No. 8, pp. 945-962.

Mathieson, A. and Wall, G. (1982), Tourism; Economic, Physical and Social Impacts, Longman, Harlow.

McElroy, J.L. (2003), "Tourism development in small islands across the world”, Geografiska Annaler Human Geography, Vol. 85 No. 4, pp. 231-242.

McElroy, J.L. and Albuquerque (2002), "Problems for managing sustainable tourism in small islands", in Apostolopoulos, Y. and Gayle, D.J. (Eds), Island Tourism and Sustainable Development: Caribbean, Pacific, and Mediterranean Experiences, (2002), Praeger, Wesport, CT.

McElroy, J.L. and Pearce, K.B. (2006), "The advantages of political affiliation: dependent and independent small-island profiles", The Round Table, Vol. 95 No. 386, pp. 529-539.

Meier, G.M. (2001), "The old generation of development economics and the new", in Meier, G.M. and Stiglitz, J.E. (Eds), Frontiers of Development Economics. The Future in Perspective, (2001), Oxford University Press, Oxford.

Meier, G.M. and Stiglitz, J.E. (2001), Frontiers of Development Economics. The Future in Perspective, Oxford University Press, Oxford.

Nikola, M. (2019), "What does overtourism really mean?", available at: https://www. adventuretravelnews.com/what-does-overtourism-really-mean (accessed 26 September 2019).

Pattulo, P. (1996), Last Resorts: The Cost of Tourism in the Caribbean, 2nd ed., Monthly Review Press (accessed 1 November 2005).

Peterson, R.R. (2009), Seeking Sustainability of Tourism Specialization in Small Island States, International Tourism Conference, University of the West Indies, Barbados.

Peterson, R.R. (2017), "Institutional capabilities for island innovation", The Caribbean in a Changing World: Surveying the Past, Mapping the Future, Cambridge Scholars Publishing, Vol. 1.

Peterson, R.R. (Ed.) (2019), Fostering Economic Resilience: From Roots to Routs. Central Bank of Aruba, available at: https://www.cbaruba.org/cba/readBlob.do?id=5788 (accessed 10 September 2019).

Peterson, R.R., Harrill, R. and DiPietro, R. (2017), "Sustainability and resilience in caribbean tourism economies: a Critical inquiry”, Tourism Analysis, Vol. 22 No. 3, pp. 407-419, 2017, (13).

Ranieri, R. and Ramos, R. (2013), Inclusive Growth: Building up a Concept, Working Paper, No. 104, UNDP, International Policy Centre for Inclusive Growth, Brasilia.

Rauniyar, G. and Kanbur, R. (2010), Inclusive Development: Two Papers on Conceptualization, Application, and the ADB Perspective, Asian Development Bank, Mandaluyong City, Philippines.

Raworth, K. (2017), Doughnut Economics. Seven Ways To Think like a 21st Century Economist, Chelsea Green Publishing, Vermont. 
IHR

35,1

Richter, L.K. (1994), “The political dimensions tourism”, in Ritchie, J.R.B. and Goeldner, C.R. (Eds), Travel, Tourism and Hospitality Research. A Handbook for Managers and Researchers, 2nd ed., John Wiley and Sons, Canada.

Scheyvens, R. and Biddulph, R. (2017), "Inclusive tourism development", Journal of Tourism Geographies: An International Journal of Tourism Space, Place and Environment, Vol. 20 No. 4, pp. 589-609, 2018.

Shani, A., Uriely, N., Reichel, A. and Ginsburg, L. (2014), "Emotional labor in the hospitality industry: the influence of contextual factors", International Journal of Hospitality Management, Vol. 37 February, pp. 150-158.

Sheller, M. (2003), Consuming the Caribbean: From Arawaks to Zombies, Routledge, London and New York.

Sönmeza, S., Apostolopoulos, Y., Lemke, M.K., Hsiehd, Y. and Karwowskie, W. (2017), "Complexity of occupational health in the hospitality industry: dynamic simulation modeling to advance immigrant worker health", International Journal of Hospitality Management, Vol. 67 October, pp. 95-105.

Statista (2020), Number of International Tourist Arrivals in the Caribbean from 2010 to 2018, available at: https://www.statista.com/statistics/816304/caribbean-number-of-tourist-arrivals/ (accessed 4 October).

United Nations Sustainable Development Goals (UNSDG) (2018), The Sustainable Development Goals Report 2018, available at: https://www.un.org/development/desa/publications/the-sustainabledevelopment-goals-report-2018.html (accessed 10 June 2019).

United Nations World Tourism Organization (UNWTO) (2019), International Tourism Statistics Data, available at: https://www.unwto.org/tourism-statistics-data (accessed 12 December 2019).

Wilkinson, P.F. (1989), "Strategies for tourism in island microstates", Annals of Tourism Research, Vol. 16, pp. 153-177.

Williams, P.W. and Ponsford, I.F. (2008), “Confronting tourism's environmental paradox: transitioning for sustainable tourism", Futures, Vol. 41, pp. 396-404.

World Bank (WB) (2018), Inclusive Growth: A Synthesis of Findings from Recent IEG Evaluations, World Bank Group, Washington, DC.

World Travel and Tourism Council (WTTC) (2019), Economic Impact Research Report 2019, available at: https://www.wttc.org/economic-impact/country-analysis/ (accessed 29 April 2019).

\section{Further reading}

Armstrong, H.W. and Read, R. (2003), "Determinants of economic growth of small states", The Round Table, Vol. 92 No. 368, pp. 99-124.

\section{Corresponding author}

Robin B. DiPietro can be contacted at: rdipietr@mailbox.sc.edu

For instructions on how to order reprints of this article, please visit our website:

www.emeraldgrouppublishing.com/licensing/reprints.htm

Or contact us for further details: permissions@emeraldinsight.com 